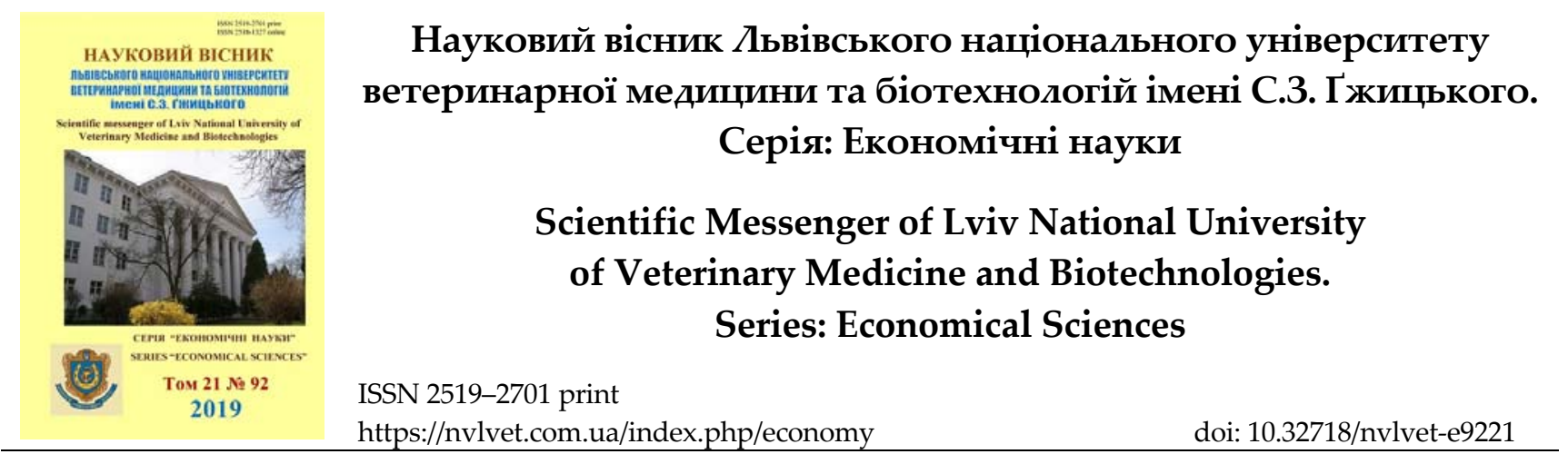

UDC 368.021.28(477)

\title{
State and trends of market development agricultural insurance of Ukraine
}

J. Muzychka, P. Muzyka, O. Dadak

Stepan Gzhytskyi National University of Veterinary Medicine and Biotechnologies Lviv, Ukraine

Article info

Received 08.02.2019

Received in revised form 11.03.2019

Accepted 12.03.2019

Stepan Gzhytskyi National University of Veterinary Medicine and Biotechnologies Lviv,

Pekarska Str., 50, Lviv, 79010, Ukraine.

Tel.: +38-067-337-07-50

E-mail: jmuzychka@ukr.net
Muzychka, J., Muzyka, P., \& Dadak, O. (2019). State and trends of market development agricultural insurance of Ukraine. Scientific Messenger of Lviv National University of Veterinary Medicine and Biotechnologies. Series: Economical Sciences, 21(92), 125-128. doi: 10.32718/nvlvete9221

The state of the agrarian insurance market in Ukraine is analyzed. The data of insurance of crops in the period from 2005 to 2018 are given. Compares the indicators of 2018 underwriting year to the indicators of previous years: the number of concluded contracts, the size of the insured sown area, the sum of insurance contracts, insurance premiums, insurance payments and the number of types of insured crops. The trend of use of combined insurance protection is monitored: insurance against total death during the period of hibernation plus spring frosts. It was determined that the reason for a sharp increase in the conclusion of contracts for animal insurance in 2018 underwriting year is the conclusion of contracts with individuals. The essence and necessity of agrarian insurance for agricultural commodity producers are determined. The role of the state in the process of organization of agrarian insurance in Ukraine is determined. Participation of the state in support of agricultural risk insurance is dictated, on the one hand, by the uniqueness of agricultural risks, and, on the other hand, the need to make financial assistance to the state of agriculture targeted and targeted. It has been determined that due to lack of budget funds and for a number of other objective reasons, the government has refused to finance the previously introduced subsidized agricultural insurance program. Therefore, the state lost the opportunity to influence the market of agrarian insurance. The general level of development of insurance of agricultural risks at the present stage is investigated and the main reasons for the reluctance of agricultural enterprises to conclude insurance contracts for the safeguarding of their crops and future yields from possible risks are identified. Among these reasons are: high level of distrust of agricultural producers to insurers and low awareness of the general mechanism of agrarian insurance. Defined tasks that need to be done to increase the interaction between insurers and insurers in the agrarian insurance sector. The issues of cooperation of the Ministry of Agrarian Policy and Food with the IFC Project "Development of Financing of the Agrarian Sector in Europe and Central Asia", which is aimed at establishing a constructive dialogue with the insurers, is disclosed. The given recommendations on introduction of an agrarian insurance pool in Ukraine.

Key words: insurance of agricultural crops, agrarian insurance, underwriting year, insurance premiums, insurance payments.

\section{Стан та тенденції розвитку ринку аграрного страхування України}

\author{
Ю.М. Музичка, П.М. Музика, О.О. Дадак
}

Львівський національний університет ветеринарної медицини та біотехнологій імені С.3. Гжицького, м. Львів, Украйна

Аналізується стан ринку аграрного страхування в Україні. Наведені дані страхування сільськогосподарських культур в період з 2005 по 2018 рік. Порівнюються показники 2018 андеррайтингового року до показників минулих років: кількість укладених договорів, величини застрахованих посівних площ, страхові суми договорів, страхові преміі, страхові виплати та кількість видів застрахованих сільськогосподарських культур. Відслідковується зберігання тендениіі використання комбінованого страхового захисту: страхування від повної загибелі на період перезимівлі плюс весняні заморозки. Визначено, щчо причиною різкого збільшення укладання договорів на страхування тварин у 2018 андеррайтинговому році є укладання договорів з фізичними особами. Визна- 
чається сутність та необхідність аграрного страхування для сільськогосподарських товаровиробників. Визначається роль держави у прочесі організачї аграрного страхування в Україні. Участь держави у підтримці страхування сільськогосподарських ризиків диктується, з одного боку, унікальністю сільськогосподарських ризиків, а з другого - необхідністю зробити фінансову допомогу держави сільському господарству адресною і цільовою. Визначено, цуо через брак бюджетних коштів та з ряду інших об 'єктивні причини уряд відмовився від фінансування раніше запровадженої програми субсидованого аграрного страхування. Тому держава втратила можливість впливу на ринок аграрного страхування. Досліджено загальний рівень розвитку страхування сільськогосподарських ризиків на сучасному етапі та визначено основні причини небажання сільськогосподарських підприємств укладати страхові договори по убезпеченню своїх посівних площ та майбутнього врожаю від можливих ризиків. Серед иих причин: високий рівень недовіри виробників сільськогосподарської продукиії до страховиків та низька обізнаність в загальному механізмі аграрного страхування. Визначені завдання, які необхідно виконати для збільшення взаємодії між страхувальниками та страховиками в аграрній страховій сфері. Розкрито питання співпрачі Міністерства аграрної політики та продовольства з Проектом ІFС “Розвиток фінансування аграрного сектору в Свропі та Центральній Азії", завданням якої є встановлення конструктивного діалогу зі страховиками. Надані рекомендащї щуодо впровадження в Україні аграрного страхового пулу.

Ключові слова: страхування сільськогосподарських культур, аграрне страхування, андеррайтинговий рік, страхові премиі, страхові виплати.

Вступ

Значні ризики, а відповідно, і значні збитки, зумовлюють високий рівень невизначеності в агропромисловому виробництві, підвищують вартість кредитів, без яких сільськогосподарське виробництво не можливе та збільшує частку неповернення кредитів. Тому система керування сільськогосподарськими ризиками є нероздільною від сільськогосподарського виробництва. Її розроблення та впровадження $є$ актуальною потребою не тільки сільськогосподарських виробників, а і держави.

Метою статті є дослідження вітчизняного ринку аграрного страхування та виявлення тенденцій на цьому ринку, опрацювання напрямків його вдосконалення як передумови стабільного розвитку аграрного сектору України.

\section{Матеріал і методи досліджень}

Об'єктом дослідження є проблеми розвитку вітчизняного ринку аграрного страхування. Дослідження здійснювались на основі застосування загальноприйнятих наукових методів. Інформаційною базою досліджень слугували нормативні та законодавчі акти, наукові публікації з проблем страхування в сільському господарстві, дані Державної служби статистики України та аналітичні дослідження Міжнародної фінансової корпорація (IFC, Група Світового банку).

\section{Результати та їх обговорення}

В сучасному світі найбільш надійним і ефективним інструментом управління сільськогосподарськими ризиками визнане аграрне страхування. Аграрне страхування - це механізм управління усіма сільськогосподарськими ризиками, який забезпечує часткову чи повну компенсацію суб'єкту господарювання втрат через негативний вплив погоди і природних ризиків (Yatsukh, 2016). В Україні сконцентровано значний потенціал розвитку страхування сільськогосподарських культур. Об'єктивна потреба в реалізації потенційних можливостей страхування зумовлена необхідністю посилення страхового захисту аграріїв із метою стабілізації їх доходів і підвищення рівня продовольчої безпеки в країні (Vilenchuk, 2017).
Маючи сприятливі природно-кліматичні умови для розвитку сільського господарства, стан цієї галузі знаходиться на досить низькому рівні, оскільки не використовується навіть половина існуючого потенціалу. Така ситуація в сільському господарстві є наслідком відсутності реальної підтримки вітчизняних аграрних підприємств з боку держави, нестачі інвестицій у розвиток сільського господарства, невикористання нових високотехнологічних засобів у процесі функціонування підприємств галузі та неврахування досвіду розвинених країн світу при вирішенні існуючих проблем (Panchenko \& Sholomii, 2017).

Унікальною особливістю агрострахування $\epsilon$ те, що воно є життєздатним у довгостроковій перспективі, як правило, лише за умови, що уряд забезпечує фінансову підтримку системи. Однак субсидії мають застосовуватися у такий спосіб, щоб система не виявилася спотвореною. Без участі держави приватні страхові та перестрахові компанії не зможуть виділити достатні фінансові кошти, щоб повною мірою відповідати за зобов'язаннями, пов'язаними з системними ризиками в сільському господарстві. Крім того, без підтримки уряду, коли страхові виплати в окремі роки будуть надзвичайно високими через стихійні лиха, такий стан справ або знеохотить приватні компанії страхувати аграрні ризики, або призведе до такої ескалації тарифів, що страхування стане недоступним для сільськогосподарських товаровиробників (Kondratenko, 2014).

Через брак бюджетних коштів та 3 інших об'єктивні причини уряд відмовився від фінансування раніше запровадженої програми субсидованого агрострахування, таким чином, держава втратила позиції активного гравця на цьому ринку. 3 певного періоду держава почала змінювати своє ставлення до ринку аграрного страхування. На сьогоднішній час Міністерство аграрної політики та продовольства тісно співпрацює з Проектом IFC “Розвиток фінансування аграрного сектору в Свропі та Центральній Азіі”, встановлює діалог зі страховиками. IFC вже інвестувала в український агросектор близько \$1 млрд, проте цього недостатньо, щоб підняти галузь.

Створення агрострахового пулу не спрацювало в Україні. Модель пулу, який використовують за кордоном не змогла існувати на ринку аграрного страхування в Україні. 
2016-й рік став першим роком, коли після тривалого періоду скорочення, ринок аграрного страхування продемонстрував деяке пожвавлення, наступні
2017-2018 роки продовжили цю тенденцію, поширивши ії на більшу кількість показників (табл. 1).

\section{Таблиця 1}

Страхування сільськогосподарських культур у 2005-2018 роках*

\begin{tabular}{lccccccc}
\hline \multicolumn{1}{c}{ Показники } & 2005 & 2010 & 2014 & 2015 & 2016 & 2017 & 2018 \\
\hline Кількість договорів & 910 & 1217 & 1392 & 1062 & 793 & 957 & 1205 \\
Площа, тис. га & 390 & 553 & 732 & 689 & 700 & 661 & 947 \\
Страхова сума, млн. грн & $\mathrm{H} /$ д & $\mathrm{H} /$ д & 3055 & 3969 & 6240 & 5933 & 6674 \\
Сума премій, млн. грн & 12,8 & 72,1 & 72,8 & 77,7 & 157,0 & 204,3 & 208,8 \\
Субсидія, млн. грн & 2,8 & 0 & 0 & 0 & 0 & 0 & 0 \\
Рівень виплат, \% & $\mathrm{H} /$ д & 50,9 & 7,6 & 12,9 & 44,2 & 4,9 & 2,8 \\
Середня ставка премій, \% & 3,8 & 3,8 & 2,4 & 2,0 & 2,5 & 3,4 & 3,1 \\
Курс \$/грн & 5,05 & 7,91 & 12,95 & 22,91 & 26,02 & 26,54 & 28,27 \\
Страхова сума, млн. \$ & н/д & н/д & 235,9 & 173,3 & 239,8 & 223,5 & 236,1 \\
Сума премії, млн \$ & 2,5 & 9,1 & 5,6 & 3,4 & 6,0 & 7,7 & 7,4 \\
\hline
\end{tabular}

* Офіційний обінний курс $\$$ до гривні на кінець жовтня місяця кожного року

Кількість договорів у 2018-му році продовжила тенденцію зростання 3 попереднім роком. Вперше, починаючи з 2009-го року, у 2018-му році значно зріс обсяг застрахованої площі більшою мірою за рахунок озимої пшениці, а також озимого ріпаку та соняшнику і незначною мірою - ярої пшениці та цукрового буряку. Премія у доларовому еквіваленті дещо зменшилась, на 0,3 млн дол. США порівняно 3 попереднім роком.

Загалом у 2018 андеррайтинговому році страхові компанії уклали 1205 договорів страхування сільськогосподарських культур та багаторічних насаджень, зокрема, 659 - на зимовий та 546 - на весняно-літній період. Загальна страхова сума за договорами страхування сільськогосподарських культур та багаторічних насаджень склала 6,674 млрд грн, що на $12,5 \%$ більше, ніж минулого року. Сума зібраних страхових премій склала 208,8 млн грн, що на 2,2\% перевищує рівень минулого року. Середня ставка страхової премії за весь андеррайтинговий рік склала $3,1 \%$.

У 2018-му андерайтинговому році здійснювалося страхування 16-ти видів сільськогосподарських культур. У порівнянні з 2017-м роком, кількість застрахованих культур залишилась сталою, але відбулися незначні зміни в структурі застрахованих культур, зокрема додалися такі культури як: озимий горох, озимий часник та троянди. Страхові виплати у 2018му андеррайтинговому році були здійснені по п'яти культурам: озимому ріпаку, озимій пшениці, озимому часнику, озимому гороху та озимому житу. Надалі зберігається тенденція використання комбінованого страхового захисту - страхування від повної загибелі на період перезимівлі плюс весняні заморозки.

У 2018-му андеррайтинговому році страхуванням тварин займалося 6 страхових компаній. Цими компаніями було укладено 3941 договорів на страхування тварин. Загальна страхова сума склала 252 млн грн, а сплачена страхова премія - 1,6 млн гривень. Відбувається тенденція появи договорів на ринку страхування тварин не лише в якості застави для отримання кредиту. Різке збільшення кількості договорів в порівнянні з минулим роком (з 23 до 3941 договорів) відбулось, переважно, завдяки укладання договорів страхування 3 фізичними особами (Rynok ahrostrakhuvannia Ukrainy..., 2018).

\section{Висновки}

Попри всі позитивні моменти, які намітилися на ринку агрострахування в Україні, його можливості використовуються з малою потужністю. Сільськогосподарські виробники часто уникають агрострахування, не розуміючи його сутності та важливості. Тому важливим елементом впливу на потенційних страхувальників мала б бути більш децентралізована просвітницька робота фахових посередників ринку страхування, а саме: агентів та брокерів. Для майбутнього пожвавлення ринку аграрного стахування необхідно вивчати найкращі світові практики агрострахування і підібрати найбільш відповідну для України модель агрострахового пулу. Аграрна галузь в Україні нині технічно та технологічно осучаснюється. За таких умов держава мала б подбати про впровадження сучасних фінансових механізмів, які змогли б посприяли подальшому іiі розвитку в напрямку аграрного страхування.

\section{References}

Kondratenko, D.V. (2014). Kontseptualni zasady rozvytku ahrostrakhuvannia v Ukraini. Biznes Inform, 8, 125-128. Rezhym dostupu: http://www.businessinform.net/export_pdf/business-inform-2014-8_0pages-125_128.pdf (in Ukrainian).

Panchenko, O. \& Sholomii, A. (2017). Rozvytok ahrostrakhuvannia v Ukraini: problemy ta perspektyvy. Problemy i perspektyvy ekonomiky ta upravlinnia, 1(9), 118-126. Rezhym dostup: https://ppeu.stu.cn.ua/tmppdf/338.pdf (in Ukrainian).

Rynok ahrostrakhuvannia Ukrainy: utochneni dani shchodo vyplat u 2017 rotsi ta poperedni dani strakhuvannia u 2018 rotsi (2018). Ofitsiinyi sait IFC. Rezhym dostupu: http://www.auu.org.ua/media/publications/ 529/files/Market\%20Survey\%20Report_2018_04_13_ 11_06_14_365993.pdf (in Ukrainian). 
Vilenchuk, O.M. (2017). Otsinka potentsialu rozvytku strakhuvannia cilskohospodarskoi produktsii $\mathrm{v}$ Ukraini. Ekonomika APK, 8, 56-64. Rezhym dostupu: http://eapk.org.ua/contents/2017/08/56 (in Ukrainian).

Yatsukh, O.O. (2016). Rynok ahrostrakhuvannia v Ukraini: stan ta perspektyvy rozvytku. Ekonomika i suspilstvo Mukachivskyi derzhavnyi universytet, 7, 866-872. Rezhym dostupu: http://www.economyandsociety.in.ua/journal/7_ukr/1 45.pdf (in Ukrainian). 